\title{
Evaluation of Quality and Food Safety Aspects of Apricot Turkel in Accelerated Conditions
}

\author{
Narendra Deo Tripathi ${ }^{1 *}$, Indu Kala Tripathi ${ }^{2}$ and Devraj Dabas ${ }^{3}$ \\ ${ }^{1}$ Department of Environmental Sciences, Mewar University, India \\ ${ }^{2}$ Department of Applied Sciences, Greater Noida Institute of Technology, India \\ ${ }^{3}$ Department of Microbiological Sciences, Central Food Technological Research Institute, India
}

Submission: November 06, 2016; Published: January 03, 2017

*Corresponding author: Narendra Deo Tripathi, Department of Environmental Sciences, Mewar University, Chittorgarh, Rajasthan, India

\begin{abstract}
The study was conducted on Apricot Turkel stored in accelerated conditions i.e. Temperature $40+2$ degree cell. and Humidity at $75+5 \%$ to evaluate its impact on apricot Turkel in terms of parameters like taste, odour, appearance, moisture content, insect infestation, total ash, acid insoluble ash, oleic acid ,aflatoxins and microbiological parameters like total plate count, yeast \& mould, E.Coli, Coliform, s.aureus, which help to determine the fact how it affect food safety aspects of product. The study was executed on retail pack of the product, available in the good retail store. Prior to initiate the study packaging integrity was assuredprecautionally. As a result of result of study of exposure in accelerated conditions and periodical analysis of Apricot Turkel at it was concluded that disintegration in the product started organoleptically, chemically and microbiologically, and there was significant alteration in the initial parameters and parameters post to the exposure in accelerated conditions.
\end{abstract}

Keywords: Accelerated conditions; Temperature; Humidity; Aflatoxins; Moisture Content

\section{Introduction}

Apricot is full of fragrance and sweet, golden-orange apricots are another summer season delicacies of Asian origin. These much-prized fruits were first brought to the Europe by Greeks, who named them as "golden eggs of the sun."Botanically, the fruit is closely related to peaches and nectarine; sharing with them in the broader Rosaceae family of fruit-trees in the genus; Prunus. Scientific name: Prunus armenia. Today, some of the chief producing regions of this fruit are Turkey, Iran, Italy, France, Spain, Syria, Greece, and China. Apricot season lasts from May until September. Buy fresh, well ripe fruits that feature uniform golden-orange color and rich aroma. Avoid those with pale yellow color as they were picked too soon. Ripened apricots are delicate and should be handled with care. Store them inside the refrigerator in tray set at high relative humidity. Use them as early as possible [1,2].

Although the apricot is native to a climate region with cold winters, it can grow in mediterranean conditions if enough cool winter weather allows a proper dormancy. A dry climate is good for fruit maturation. The tree is slightly more cold-hardy than the peach, tolerating winter temperatures as cold as $-30^{\circ} \mathrm{C}\left(-22^{\circ} \mathrm{F}\right)$ or lower if healthy. A limiting factor in apricot culture is spring frosts: They tend to flower very early (in early March in western Europe), meaning spring frost can kill the flowers. Furthermore, the trees are sensitive to temperature changes during the winter season. In China, winters can be very cold, but temperatures tend to be more stable than in Europe and especially North America, where large temperature swings can occur in winter. Hybridization with the closely related to Siberian apricot; hardy to $-50^{\circ} \mathrm{C}\left(-58^{\circ} \mathrm{F}\right)$ but with less palatable fruit offers options for breeding more cold-tolerant plants. Apricots are rich source of fibers and therefore good for smooth bowel movements $[1,2]$. It is often recommended to patients who are regularly suffering from constipation due to its laxative properties.

Apricots are also good source of minerals i.e calcium, Phosphorous, manganese, iron and copper, all plays certain role in the creation of bone matter. Apricots have unique natural therapeutic qualities as its regular usage protect heart from vide 
range of diseases including atherosclerosis, heart attack strokes. The apricot juices very useful to the patients suffering from fever as it provide necessary vitamins, minerals and calories to body, it also helps in detoxification of system and organs.

Apricots are excellent sources of vitamin-A, and carotenes. $100 \mathrm{~g}$ fresh fruits carry $1926 \mathrm{IU}$ or $64 \%$ of daily-required levels of vitamin A. Both of these compounds are known to have antioxidant properties and are essential for vision. Vitamin-A is also required for maintaining healthy mucusa and skin. Consumption of natural fruits rich in carotenes helps protect the body from lung and oral cavity cancers. Fresh fruits contain vitamin-C, another natural anti-oxidant. Vitamin-C helps the body develop resistance against infectious agents and scavenge harmful oxygen-free radicals.

The total anti-oxidant or ORAC value of raw apricots is 1115 umol TE/100 g. Much of this in these fruits comes from some important health promoting flavonoid poly phenolic antioxidants such as lute in, zeaxanthin and beta cryptoxanthin. Altogether, these compounds act as protective scavengers against oxygen-derived free radicals and reactive oxygen species (ROS) that play a role in aging, cancers and various disease processes [3,4].

\section{Area of study}

The study was conducted in the National capital region (NCR), in association with companies dealing in dry fruits specifically in Apricot Turkel. These fruits are imported and reprocessed and repacked hygienically before keeping in supply chain for distribution in the market for consumer usage.

Sampling: Packed samples were picked up from the processing and repacking site. During sampling standard quality practices were followed and total 05 samples were collected from five different lots of same batch number. The study was conducted in year 2014-2015.

Inspection of samples: The samples were packed in Thermacoal trays, and finally shrink-wrapped using poly film. The integrity of samples were checked thoroughly. As a result of inspection:

i) Pin whole : No pin whole on the poly film, as observed through naked eyes and magnifying glasses

ii) Sealing condition: Sealing was in good state.

iii) Damage patches : Thermacoal Tray was found intact with poly film

\section{iv) Package integrity : Compactly packed}

Packaging Material composition: The packing material was composed of poly having thickness of 20 micron. The packing material was uniaxial stretchable which can be wrapped easily on packs even without help of shrink Tunnel.

\section{Process flow}

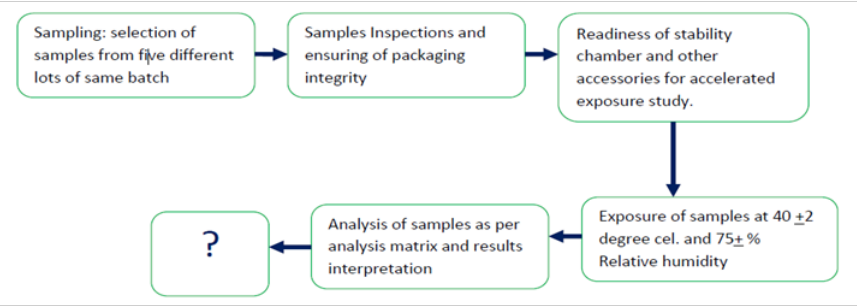

A. Requirement for study: Adequately packed samples of Apricot Turkel, Humidity chamber to maintain accelerated exposure conditions i.e. Temperature $40+2$ degree cel. And Relative Humidity 75+ 5\%. Hot air oven, Muffel furnace and functional microbiological set up to assure timely microbiological analysis. The availability of consumable chemicals and technical analyst were assured prior to startup of the experimental study. The exposure of sample was monitored sincerely to assure that there is no Fluctuation in temperature and humidity. Walk-In Stability chamber make Thermo lab was used for exposure study. The exposure of sample was monitored sincerely to assure that there is no Fluctuation in temperature and humidity, however the equipment was software based and there was auto recording of temperature and humidity and it was monitored through system.

Table 1: Content showing parameters of analysis.

\begin{tabular}{|c|c|c|c|}
\hline S. No. & Parameters & $\begin{array}{l}\text { Method of } \\
\text { analysis }\end{array}$ & $\begin{array}{l}\text { Frequency } \\
\text { of analysis }\end{array}$ \\
\hline 1 & Taste & Organoleptic & \multirow{14}{*}{$\begin{array}{l}\text { Initial } \\
\text { prior to } \\
\text { exposure, } \\
\text { and every } \\
\text { fortnightly }\end{array}$} \\
\hline 2 & Odour & Organoleptic & \\
\hline 3 & Appearance & Visual Inspection & \\
\hline 4 & Moisture Content & $\begin{array}{l}\text { Hot air oven @130- } \\
133 \\
\text { deg. for } 120 \\
\text { minutes }\end{array}$ & \\
\hline 5 & Insect infestation & Visual inspection & \\
\hline 6 & Total Ash & $\begin{array}{l}\text { Chemical analysis } \\
\text { and } \\
\text { gravimetric } \\
\text { estimation }\end{array}$ & \\
\hline 7 & Acid Insoluble Ash & Chemical analysis & \\
\hline 8 & Oleic Acid & Chemical analysis & \\
\hline 9 & Aflatoxins(B1,B2,G1,G2) & AOAC method & \\
\hline 10 & Total Plate Counts & $\begin{array}{l}\text { Microbiological } \\
\text { analysis }\end{array}$ & \\
\hline 11 & Yeast and Mould & $\begin{array}{c}\text { Microbiological } \\
\text { analysis }\end{array}$ & \\
\hline 12 & E. coli & $\begin{array}{c}\text { Microbiological } \\
\text { analysis }\end{array}$ & \\
\hline 13 & Coliform & $\begin{array}{l}\text { Microbiological } \\
\text { analysis }\end{array}$ & \\
\hline 14 & S. Aureus & $\begin{array}{l}\text { Microbiological } \\
\text { analysis }\end{array}$ & \\
\hline
\end{tabular}


B. Analysis: The analyses of samples were conducted at two stages. The first stage analysis was conducted before exposure of product in accelerated conditions i.e. called as initial analysis, followed by analysis at defined interval. The parameters covers under analysis are as tabulated in Analytical matrix (Table 1).

C. Physical and Chemical Analysis: Taste \& odour of the product was analyzed through organoleptic method of analysis for sensory team was built based on Indian standards Guidelines, prior to startup of analysis the sensory panelist were validated. The results were recorded systematically to conclude the final results. Appearance of the product was also analyzed through sensory panel. The insect infestation in the product was analyzed through visual inspection. Pertaining to the determination of moisture content product (5.0 gram sample) was exposed at 130-133 degree cel. For two hours and reading was noted post to the constant three successive readings. Total ash was determined by using Muffle furnace for which 5.0 gram sample quantity was exposed at 800 degree cel. For four hours, followed by cooling of sample in desiccators and weighing using calibrated weighing balance, till constant readings of samples.

\section{Calculation:}

Total Ash, percent by mass= 100(M2-M1) M1-M

Where,

$\mathrm{M}=$ Mass of the empty dish, in $\mathrm{g}$

M1 = mass of the dish with the material taken for test, in $g$ and $\mathrm{M} 2=$ mass of the dish with the ash, in $\mathrm{g}$

The similar steps were followed as in case Total ash for the determination of acid insoluble ash, additional step was dissolving and drying of estimated ash content in hydrochloric acid. The calculation was done based on the formula as under:

\section{Calculation:}

(Weight of crucible with residue - weight of empty crucible) $\mathrm{x} 100$

Acid insoluble Ash \% =

Weight of the sample

The measurement of Oleic acid was done in terms of peroxide value (POV).The test sample was first dissolved in mixture of chloroform and acetic acid(2:3). By flowing nitrogen gas through the sample to dispel residual oxygen, add potassium iodide, and then titrate free iodine with $0.01 \mathrm{~mol} / \mathrm{L}$ sodium thiosulphate. The endpoint was determined by the maximum inflexion point on titration curve. POV is calculated from titration volume of sodium thiosulphate. $\mathrm{I} 2+2 \mathrm{Na} 2 \mathrm{~S} 2 \mathrm{O} 3 \rightarrow \mathrm{Na} 2 \mathrm{~S} 4 \mathrm{O} 6+2 \mathrm{NaI}$

The analysis of Aflatoxins (B1, B2, G1, G2) was carried out using LC/MS/MS,
Aflatoxins (AFs) belong to a closely related group of secondary fungal metabolites. These mycotoxins are severely toxic metabolites produced mainly by Aspergillus flavus and A. parasiticus, and exposure to them can cause cancer in humans and livestock. Based on epidemiological evidence, Aflatoxins have been classified as human liver carcinogens by the World Health Organization and by the U.S. Environmental Protection Agency. Thus, accurate determination of AFs is required to avoid human.

Each of the standard reagents, Aflatoxin G2 (AFG2), Aflatoxin G1 (AFG1), Aflatoxin B2 (AFB2) and Aflatoxin B1 (AFB1), was dissolved in acetonitrile at $1 \mathrm{mg} / \mathrm{mL}$ and was stored at $4{ }^{\circ} \mathrm{C}$ in the dark until use. To prepare the working standard for LC/ MS analysis, each AF stock solution was equally pipetted and transferred to a vial, and it was then diluted with the mobile phase. The final concentration of each AF was $1 \mathrm{ng} / \mathrm{mL}$.

The extraction and cleanup steps for Aflatoxins (B1, B2, G1, G2) were carried out according to validated methods. Briefly, $20 \mathrm{~g}$ fine ground sample was poured into a 200-mL Erlenmeyer flask, followed by adding $40 \mathrm{ml}$ acetonitrile-water $(9: 1, \mathrm{v} / \mathrm{v})$ for corn and cereals. After shaking for $30 \mathrm{~min}$, the mixed solution was centrifuged for $5 \mathrm{~min}$ at 1,650g. The supernatant obtained was filtered through a glass microfiber GF/B grade filter. The required conditions of $\mathrm{LC} / \mathrm{MS} / \mathrm{MS}$ was maintained till the completion of analysis of product. The method of quantification was applied to determine the quantitative value of Aflatoxins (B1, B2, G1, G2) [5-7].

\section{Microbiological Analysis}

Prior proceeding of microbiological analysis the calibration of equipment like incubator and BOD incubator was assured IS 5402: 2012was used for determination of bacterial count in the product. This Indian Standard (Second Revision) which is identical with ISO 4833:2003 'Microbiology of food and animal feeding stuffs, Horizontal method for the enumeration of microorganisms, Colony-count technique at $30^{\circ} \mathrm{C}$ ' issued by the International Organization for Standardization (ISO) was adopted by the Bureau of Indian Standards on the recommendation of the Food Hygiene, Safety Management and Other Systems Sectional Committee and approval of the Food and Agriculture Division Council. Sample preparation was done as per procedure of ISO 6887 and specified conditions were maintained $[8,9]$.

Plate Count Agar Media was used having composition i.e. enzymatic digestion of casein, Yeast Extract, Glucose anhydrous and Agar water. The pouring technique was used for plating and followed the incubation of samples in incubator at 30 degree cel.+1 deg. Cel. For the period of $72 \mathrm{~h}+3 \mathrm{~h}$. Post to the completion of incubation duration Petri dishes were taken out from the incubator and number of colonies were observed using colony count apparatus, followed by reporting of results. The repeatability and reproducibility we reassured before providing confirmatory results $[8,9]$. 
The analysis of yeast and mould was conducted using IS 5403: 1999(Reaffirmed: 2005) Yeast and mould is the microorganism which form colonies in selective medium of nutrients at $25+1$ deg.cel. During preparation of dilution guideline IS10232 was followed .Yeast Extract-Dextrose-ChloramphenicolAgar medium was used during analysis. The components of medium were dissolved in the water by boiling, $\mathrm{pH}$ was adjusted as per requirement i.e. 6.6.Dispensed the agar medium into suitable container and followed by its sterilization at $121+1$ deg. Cel. The glass wares were subjected for dry sterilization at 170 deg. cel. For one hr. The sample (1 gram) and medium (15 $\mathrm{ml}$ ) were poured in petri dishes, followed by protection with inverted plates and incubated in incubator already having set temperature of $25+1 \mathrm{deg}$. Cel. The counting of colonies were started after 3,4 , and $5^{\text {th }}$ days. The number of colonies of each days were noted and final reading was taken after completion of $5^{\text {th }}$ days i.e. $120 \mathrm{hrs}$ of incubation.

The analysis of E.Coli was conducted as per IS standard, IS: 5887 (Part I) -1976 and IP-14. The sampling of product was done using methodology of IS: 5404-1969 [8,9]. The typical Escherichia coli is aerobic, Gram-negative rod, motile, fermenting lactose with the production of gas and usually produces smooth, non-mucoidcoloni'es on solid media. However, there are nonlactose fermenting strains of Esch. Coli and some strains produce mucoid colonies. The organism exhibit the characteristics as below:

a) Hydrogen sulphide $(\mathrm{HzS})$ production when done in TSI medium: Negative
b) Urease: Negative
c) Indole : Positive
d) Methyl red : Positive
e) Voges-Proskauer test : Negative
f) Sucrose : Acid and gas production variable
g) Salicin : Acid and gas production variable, and
h) Growth at $44^{\circ} \mathrm{C}$ in Mac Conkey broth medium: Positive with acid and gas.

Took Pipette $1 \mathrm{ml}$ sample of the three Mac Conkey broth tube aseptically \& Plug the tube with cotton plug and keep in an incubator at $35 \pm 20 \mathrm{C}$ for 48 hours. Observed the tubes for any acid and gas formation. If Acid and gas formation in at least two tubes out of three constitutes a positive presumptive test. Further for confirmation of the result streak loop full sample from the positive tubes of presumptive test $\&$ incubate the plates in an inverted position at $35 \pm 2$ oC for $24 \mathrm{hrs}$. After incubation observed the nature of colonies formed. Presence of Escherichia coli indicated by the colonies with a typical green metallic sheen.

\section{Escherichia coli=X MPN/g}

The analysis of Coliform was conducted using standard IS 15185:2002(ISO 9308-1:2000). Coliform bacteria is capable of forming colonies aerobically at $36+3 \mathrm{deg}$. on a selective and differential lactose culture medium with the production of acid within $(21+3) \mathrm{h}$. It is lactose positive and oxidase negative bacteria.

The sample was prepared using filtration, inoculation and isolation media. During preparation of sample the guidelines of ISO: 8199 and ISO: 6887-1 were followed. The prepared sample was kept ambient temperature i.e. not more than 25 degree cel. in dark condition for two hrs only. After completion of filtration the membrane was placed on TTC agar plate under incubation for $21+3 \mathrm{hrs}$ for oxidase test and conclusion of final results.

The analysis of S. Aureus was performed using IS: 5887 (Part II) - 1976 and IP-14 Aerobic, Gram-positive cocci in clusters, usually, but not always producing a golden yellow coloured colonies on nutrient agar and blood agar and shiny black colonies with or without narrow grey-white margin.

i) Pretreatment of Sample: Weight accurately $10 \mathrm{gm}$ of sample on the calibrated weighing balance or pipette $10 \mathrm{ml}$ sample with the help of sterile pipette and suspend or dissolve it in $90 \mathrm{ml}$ of Nutrient Broth or Soyabean Casein Digest Medium or Fluid Lactose Medium or Buffered sodium chloride peptone solution. When the sample has known antimicrobial properties add $0.5 \%$ Soya lecithin or $1 \%$ Poly-Sorbate 80 (or as per the customer specification) in the above medium to inactivate antimicrobial property of the sample $[8,9]$.

ii) Enrichment: Inoculated $100 \mathrm{~m}$ of Soybean Casein Digest broth with the pretreated sample quantity equivalent to $1 \mathrm{gm}$ or $1 \mathrm{ml}$ of the product or as per the quantity of the product specified. Mix and incubate at 35-37oC for $24 \mathrm{hrs}$.

iii) Primary and Coagulate Test: The growth was observed, followed by streaking a portion of the medium on the surface of Vogel- Johnson agar or Mannitol-salt agar or Baird-Parker agar. Incubate the plates in an inverted position at $35 \pm 2^{\circ} \mathrm{C}$ for 18 to 24 hours. Post to the incubation the colonies conforming description test were forwarded for coagulase test As result of coagulase test no coagulation in any degree was observed, It showed that Staphylococcus aureus is absent in the product. (Tables 2 to 6) (Graphs 1 to 4 )

Table 2: Showing initial and fortnightly interval analytical results i.e. up to $30^{\text {th }}$ day of incubation exposure.

\begin{tabular}{|c|c|c|c|}
\hline & & Results & $\mathbf{3 0}^{\text {th }}$ day \\
\hline & Initial Testing & $\mathbf{1 5}^{\text {th }}$ day & \\
\hline \multicolumn{4}{|c|}{ Physical/Chemical } \\
\hline Moisture content & $14.92 \% \mathrm{w} / \mathrm{w}$ & $16.90 \% \mathrm{w} / \mathrm{w}$ & $30.04 \% \mathrm{w} / \mathrm{w}$ \\
\hline
\end{tabular}


International Journal of Environmental Sciences \& Natural Resources

\begin{tabular}{|c|c|c|c|}
\hline Insect infestation & Nil & Nil & Nil \\
\hline Taste & Fruity taste & Fruity taste & NA, Due to fungal \\
growth
\end{tabular}

Table 3: Showing fortnightly interval analytical results i.e. up to 60th day of incubation exposure.

\begin{tabular}{|c|c|c|}
\hline \multirow{2}{*}{ Parameters } & \multicolumn{2}{|c|}{ Results } \\
\hline & $45^{\text {th }}$ Day & $6^{\text {th }}$ Day \\
\hline \multicolumn{3}{|c|}{ Physical/Chemical } \\
\hline Moisture content & $32.04 \% \mathrm{w} / \mathrm{w}$ & $34.73 \% \mathrm{w} / \mathrm{w}$ \\
\hline Insect infestation & Nil & Nil \\
\hline Taste & Not done, Due to fungal growth & Not done, Due to fungal growth \\
\hline Odour & Off odour, having fermented smell & Off odour, having fermented smell \\
\hline Appearance & $\begin{array}{l}\text { Yeast \& mold appear on the Body } \\
\text { surface, }\end{array}$ & $\begin{array}{l}\text { Yeast and mold appear on the Body } \\
\text { surface, }\end{array}$ \\
\hline Total Ash & 3.18 & $2.46 \% \mathrm{w} / \mathrm{w}$ \\
\hline Acid Insoluble Ash & $0.09 \% \mathrm{w} / \mathrm{w}$ & $0.08 \% \mathrm{w} / \mathrm{w}$ \\
\hline Oleic Acid & $0.34 \%$ & $0.46 \%$ \\
\hline Aflatoxins(B1,B2,G1,G2) & $10.2 \mathrm{ppb}$ & $15.5 \mathrm{ppb}$ \\
\hline \multicolumn{3}{|c|}{ Microbiological } \\
\hline Total Plate Count & $85,60,000 \mathrm{cfu} / \mathrm{g}$ & $85,80,000 \mathrm{cfu} / \mathrm{g}$ \\
\hline Yeast \& Mould & $37,55,000 \mathrm{cfu} / \mathrm{g}$ & $37,65,000 \mathrm{cfu} / \mathrm{g}$ \\
\hline E. Coli & Absent/g & Absent/g \\
\hline Coliform Count & Less than $10 \mathrm{cfu} / \mathrm{g}$ & Less than $10 \mathrm{cfu} / \mathrm{g}$ \\
\hline S. Aureus & Absent/g & Absent/g \\
\hline
\end{tabular}

Table 4: Showing summary of analytical results.

\begin{tabular}{|c|c|c|c|c|c|}
\hline \multicolumn{7}{|c|}{ Summary of chemical analysis Results } \\
\hline Parameters & Initial & $\mathbf{1 5}^{\text {th }}$ Days & $\mathbf{3 0}^{\text {th }}$ Days & $\mathbf{4 5}^{\text {th }}$ days & $\mathbf{6 0}^{\text {th }}$ Days \\
\hline Moisture content (\%w/w) & 14.92 & 16.9 & 30.04 & 32.04 & 34.73 \\
\hline Total Ash(\% w/w) & 4.59 & 4.42 & 3.59 & 3.18 & 0.46 \\
\hline Acid insoluble ash(\%w/w) & 0.13 & 0.11 & 0.10 & 0.09 & 0.08 \\
\hline Oleic Acid(\%) & 0.07 & 0.09 & 0.18 & 0.34 & 0.46 \\
\hline
\end{tabular}


International Journal of Environmental Sciences \& Natural Resources

Table 5: Showing result alteration in Chemical parameters.

\begin{tabular}{|c|c|c|}
\hline Parameters & Difference from Initial Parameters & Alteration \% \\
\hline Moisture content $(\% \mathrm{w} / \mathrm{w})$ & 19.81 & 132.8 \\
\hline Total Ash $(\% \mathrm{w} / \mathrm{w})$ & 2.13 & 46.4 \\
\hline Acid insoluble ash $(\% \mathrm{w} / \mathrm{w})$ & 0.05 & 38.5 \\
\hline Oleic Acid(\%) & 0.39 & 557.14 \\
\hline
\end{tabular}

Microbiological Parameters:

Table 6: Showing result alteration in Microbiological

\begin{tabular}{|c|c|c|c|}
\hline & $\mathbf{3 0}^{\text {th }}$ Day & $\mathbf{6 0}^{\text {th }}$ day & Day \\
\hline Total Plate Count & $85,50,000 \mathrm{cfu} / \mathrm{g}$ & $85,60,000 \mathrm{cfu} / \mathrm{g}$ & $85,80,000 \mathrm{cfu} / \mathrm{g}$ \\
\hline Yeast and Mould & $37,50,000 \mathrm{cfu} / \mathrm{g}$ & $37,55,000 \mathrm{cfu} / \mathrm{g}$ & $37,65,000 \mathrm{cfu} / \mathrm{g}$ \\
\hline
\end{tabular}
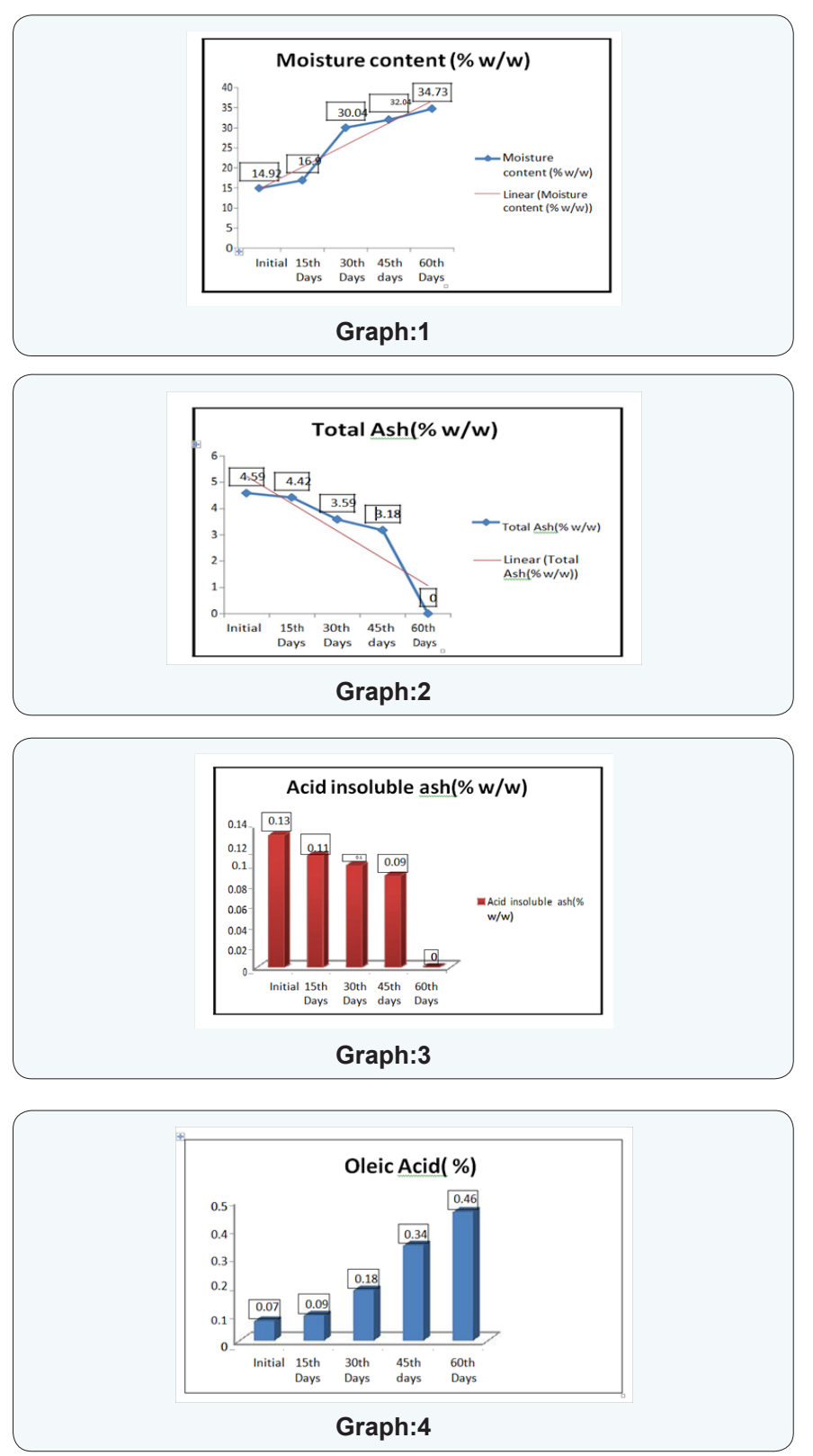

\section{Discussion and Conclusion}

The experimental study conducted on Apricot Turkel shows that there are significant changes when it is exposed in accelerated conditions i.e. at 40 degree cel. Temperature and 75 $\%$ humidity. The initial characteristics of products stand within the range of standards of quality and food safety and product remain safe for consumption. The analysis shows that the results of parameters are changing with the exposure duration even at constant temperature and humidity There is $132.8 \%$ $\mathrm{w} / \mathrm{w}$ alteration from initial to $60^{\text {th }}$ days of exposure in moisture content .Total ash is altering from $2.13 \% \mathrm{w} / \mathrm{w}$ to $46.4 \% \mathrm{w} / \mathrm{w}$, whereas acid insoluble ash and oleic acid contents are changing $0.05 \% \mathrm{w} / \mathrm{w}$ to $38.5 \%$ and $0.39 \% \mathrm{w} / \mathrm{w}$ to $557.14 \%$ (permissible limit of oleic acid i.e. in terms of acidity of extracted fat $1.25 \%$ maximum, ref FSSAR-2011) respectively [10,11]. Apart of changes in chemical parameters microbiological parameters i.e. Total Plate count and Yeast and Mould are getting altered significantly (Figures $1 \& 2$ ).

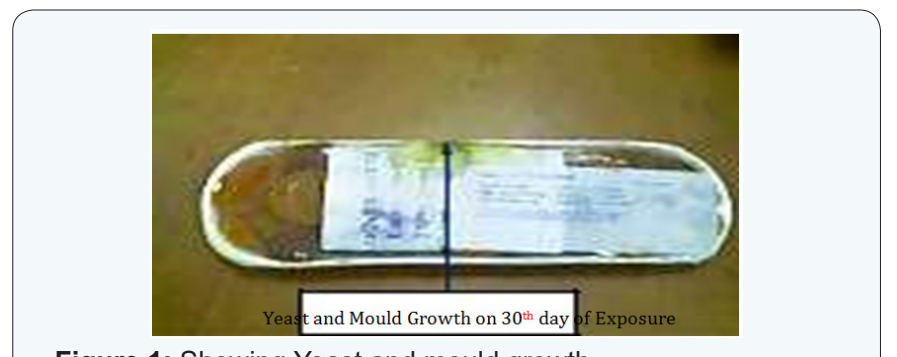

Figure 1: Showing Yeast and mould growth.

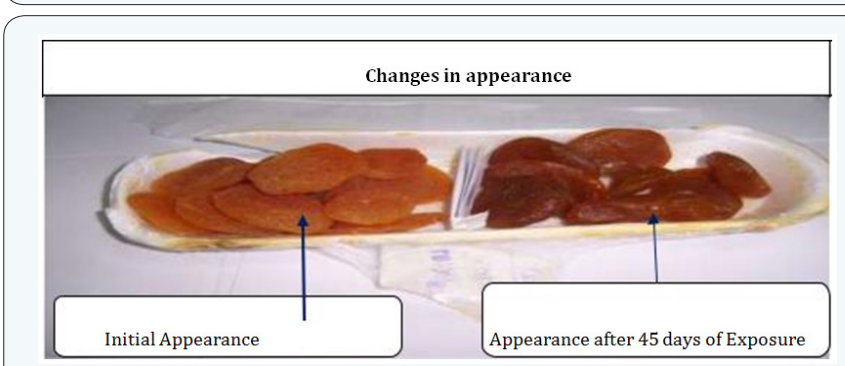

Figure 2: Showing changes in appearance of product from initial to post exposure of 45 th days.

The reported Total plate count in the sample at $60^{\text {th }}$ day stand as $85,80,000 \mathrm{cfu} / \mathrm{g}$ whereas permissible limit of Total Plate count as per FSSAR-2011, Not more than $40,000 \mathrm{cfu} / \mathrm{g}$. Yeast and mould count was reported on $60^{\text {th }}$ day $, 37,65,000 \mathrm{cfu} /$ $\mathrm{g}$, the permissible limit for the same as per FSSAR-2011 stand as Not more than 100 count/g. Based the data interpretation it is 
concluded that storage of Apricot Turkel at Higher temperature and humidity is not safe for product [10-15]. It is clear that higher temperature and humidity play significant role to alter the chemical composition and microbiological load of the product, which finally make product unsafe for consumption .

\section{References}

1. Kumar P, Mishra HN ( 2004) storage stability of mango soy fortified yoghurt powder in two different packaging materials: HDPP and ALP J Food Eng 65(4): 569-576.

2. Jaya S, Das H ( 2005) Accelerated storage, shelf life and color of Mango Powder. J Food Process Pres 29(1): 45-62.

3. K K Sinha, D Bhatnagar (1998) Mycotoxins in Agriculture and Food Safety.

4. Food Safety Authority of India.

5. Dry Fruit Storage https://en.wikipedia.org/wiki/Dried_fruit

6. Atanda S A, Pessu P 0, Agoda S et al. (2011) The concepts and problems of post-harvest food losses in perishable crops. African Journal of Food Science 5 (11): 603-613.

7. Canellas J, Rosella C, Simal S, Soler L, Mulet A (1993) Storage conditions affect quality of raisins. Journal of Food Science 58(4): 805-809.
8. Gopal TKS, Nair PGV, Kandoran MK, Prabhu PV, Gopakumar K (1998) Shelf life of dried anchoviella in flexible packaging materials. Food Control 9(4): 205-209.

9. W J Hurst, R A Martin, C H Vestal (1991) The Use of HPLC/Thermo spray MS for the Confirmation of Aflatoxins in Peanuts. J Liq Chromatograph 14(13): 2541-2550.

10. M Vahl, K Jorgensen (1998) Determination of Aflatoxins in Food Using LC/MS/MS. Z Lebensm Unters Forsch A 206(4): 243-245.

11. Analytical methods of Indian Standards. IS 5402:2012, IS 5403:1999, IS 5887(I):1976,IS 5887(II):1976,IS1585:2002.

12. AOAC (1990) Official method of analysis of the Association of Official Analytical Chemist № 934.06. Arlington USA.

13. RE Mullen, Gladys C Y, Susana Goggi, Leonor F S Leandro (2013) Effects of Storage Temperature and Relative Humidity on Viability and Vigor of Treated Soya bean seeds. Crop Sci. 53: 1086-1095.

14. Chattopadhyay N (2008) Climate Change and Food Security in India. International Symposium on Climate Change and Food Security in South Asia.

15. David Battisti S, Naylor RL (2009) Historical warnings of future food Insecurity with unprecedented seasonal heat. Science 323(5911): $240-244$.

Your next submission with JuniperPublishers will reach you the below assets

- Quality Editorial service

- Swift Peer Review

- Reprints availability

- E-prints Service

- Manuscript Podcast for convenient understanding

- Global attainment for your research

- Manuscript accessibility in different formats ( Pdf, E-pub, Full Text, Audio)

- Unceasing customer service

Track the below URL for one-step submission https://juniperpublishers.com/online-submission.php 